\title{
Analisis Pelaksanaan Microteaching Mahasiswa Program Studi Pendidikan Agama Islam
}

\author{
Khuriyah \\ IAIN Surakarta \\ e-mail: Khuriyah98@gmail.com
}

\begin{abstract}
The problem in this research is the implementation of microteaching in PAI departement FITK IAIN Surakarta has not been evaluated and need to know the urgency after the existence of several courses of learning strategy that is substantially the same as the implementation of microteaching activities.The research method used is descriptive, carried out for three months since April-June 2016. The population of this research is the students of semester $V$ of academic year 2015/2016 that follow the microteaching of 450 students, the research sample is 260 students. The results show that: 1) The implementation of microteaching as a whole has fulfilled the provisions of microteaching implementation as stated in the microteaching guide book. Each student performs teaching practice as much as 4-5 times, previously required to prepare RPP which will be reviewed and corrected by supervisor (DPL). In implementing the teaching practice, students are required to practice one of the teaching strategies in accordance with the material to be submitted; 2) Although the students have obtained several courses of instructional strategies that note more of the practice of teaching both groups and individuals, but $81 \%$ of students stated that microteaching is still needed.
\end{abstract}

Keywords: Analysis, Microteaching. 


\section{Pendahuluan}

Standar kelulusan mahasiswa jurusan kependidikan di berbagai Perguruan Tinggi di antaranya adalah mampu menjadi pendidik/pengajar. Untuk mampu menjadi seorang pendidik dan pengajar yang professional diperlukan beberapa bekal pengetahuan dan keterampilan. Sebagaimana disebutkan dalam UU No.14 Tahun 2005 tentang Guru dan Dosen. "Seorang guru wajib memiliki kualifikasi akademik, kompetensi, sertifikasi pendidik, sehat jasmani dan rohani serta memiliki kemampuan mewujudkan tujuan nasional.” Oleh karena itu, dalam melaksanakan kegiatannya calon guru menitikberatkan pada aspek-aspek yang erat kaitannya dengan masalah keguruan dan ilmu pendidikan sehingga diharapkan lulusan jurusan kependidikan, kelak dapat menguasai kompetensi sebagai tenaga profesional di bidang pendidikan.

Mengajar merupakan kegiatan yang dominan bagi seorang guru. Kegiatan mengajar menurut Ololube dalam Ajileye (2013) dapat disebut sebagai kegiatan multidimensional, dan sangat kompleks. Agar guru dapat mempunyai performance yang baik dan benar dalam mengajar maka guru harus dapat mengajar secara efektif. Pengajaran yang efektif merupakan kegiatan yang berbasis pada kemampuan kognitif, afektif, dan interpersonal.

Untuk menjadi tenaga professional, mahasiswa diberi bekal pengetahuan berupa pemberian mata kuliah kependidikan seperti perencanaan pembelajaran, media pembelajaran, strategi pembelajaran, dan masih banyak lagi yang lainnya. Semua pengetahuan tersebut diimplementasikan dalam beberapa kegiatan praktik yang berupa microteaching dan Praktek Pengalaman Lapangan (PPL).

Sebagaimana yang disebutkan oleh Mastromarino dalam Imran Mahmud (2013) bahwa untuk membantu mahasiswa mengaplikasikan pengetahuannya perlu diterapkan microteaching. Microteaching akan sangat membantu mahasiswa dalam berkomunikasi dengan siswa yang sesungguhnya. Microteaching merupakan sebuah media latihan bagi mahasiswa jurusan kependidikan sebelum melakukan praktik pengalaman lapangan (PPL) di sekolah praktikan. Microteaching juga merupakan sarana bagi mahasiswa melatih kemampuan mengajar dalam lingkup lebih kecil. Pembelajaran micro dapat diartikan sebagai cara latihan keterampilan keguruan atau 
Analisis Pelaksanaan Microteaching Mahasiswa Program Studi Pendidikan Agama Islam

praktik mengajar dalam lingkup kecil/terbatas. Knight dalam Asril (2012:43) mengemukakan micro teaching has been describelas scaled down teaching encounter designed to develop new skills andrefine old ones.

Pelaksanaan microteaching di FITK telah berlangsung sejak tahun 1999. Mahasiswa melakukan praktek mengajar sebanyak 5x pada kelas kecil dan teman dalam satu kelompok berperan seolah-olah menjadi siswa. Setelah melakukan microteaching, pada semester berikutnya siswa mengadakan praktek pengalaman lapangan atau praktek mengajar sungguhan di sekolah praktikan.

Berdasarkan hasil pra observasi (Februari 2016) secara teoritis, mahasiswa telah memperoleh bekal mata kuliah strategi pembelajaran. Khusus untuk mahasiswa PAI, mata kuliah strategi pembelajaran yang diberikan terdiri dari strategi pembelajaran Fiqh, Aqidah Akhlak, Qur'an Hadis, dan Sejarah Kebudayaan Islam (SKI). Dalam prosesnya, mahasiswa diminta untuk mengimplementasikan satu atau dua strategi pembelajaran dalam sebuah simulasi pengajaran. Artinya, pada mata kuliah tersebut, mahasiswa telah berlatih menjadi seorang guru mulai dari perencanaan (menyusun RPP) hingga evaluasi dalam proses pembelajaran. Pada saat mata kuliah strategi pembelajaran, mahasiswa melakukan praktek mengajar minimal 2x. Jika pada program studi PAI terdapat 4 mata kuliah strategi pembelajaran, hal ini berarti mahasiswa telah melakukan praktik mengajar sebanyak 6-8 kali. Praktik mengajar yang mereka lakukan juga pada kelas yang tidak sesungguhnya, temanteman mahasiswa bertindak sebaga siswa, dan hanya berdurasi 15-20 menit. Dengan kata lain, pada saat perkuliahan strategi pembelajaran pun mahasiswa telah melakukan microteaching bahkan dengan jumlah peserta yang lebih banyak.

Akan tetapi pada praktiknya, dalam kegiatan microteaching mahasiswa masih terkendala dalam beberapa hal di antaranya; RPP yang masih salah, penyampaian materi yang masih tekstual, penggunaan metode atau strategi yang masih monoton, dan kurangnya komunikasi mahasiswa.

Melihat realitas sebagaimana yang diuraikan di atas, maka evaluasi terhadap pelaksanaan microteaching merupakan satu hal yang harus dilakukan. Dengan demikian permasalahan akan diangkat dalam penelitin ini adalah: 1) Bagaimana gambaran pelaksanaan microteaching pada mahasiswa Juruan PAI di FITK IAIN 
Surakarta tahun 2016? 2) Apakah microteaching masih relevan bagi mahasiswa jurusan PAI?

Melalui pertanyaan penelitian tersebut, penelitian tentang analisis pelaksanaan microteaching pada mahasiswa Jurusan PAI ini secara khusus memberikan kontribusi bagi Jurusan PAI. Berdasarkan hasil penelitian ini akan diketahui pelaksanaan microteaching, dan urgensi microteaching bagi mahasiswa PAI.

\section{Microteaching}

Microteaching merupakan sebuah metode peningkatan kemampuan keterampilan mengajar yang dikembangkan di Universitas Stanford pada tahun 1963 (Imran Mahmud, Shahriar Rawshon, 2013). Munculnya microteaching dilatar belakangi adanya permasalahan dalam mempersiapkan guru yang efektif karena adanya kompleksitas aspek pengajaran, adanya perbedaan antara teori dan praktik. Oleh karena itu, dibutuhkan sebuah kondisi yang praktis yang mampu menjembatani antara teori dan praktek .

Microteaching menurut B. Veena dan Digumarti (2004) adalah

is a training procedure aiming at simplifying the complexities of the reguler teaching process. Micro teaching is real teaching, althought a teaching situation is constructed in which the student teacher and pupils work together in a practice situation.

Micro berarti kecil, terbatas, sempit, sedangkan teaching berarti mengajar. Pengajaran mikro (microteaching) adalah suatu situasi pengajaran yang dilaksanakan dalam waktu dan jumlah siswa yang terbatas, yakni selama 4 sampai 20 menit dengan jumlah siswa sebanyak 3 sampai 10 orang. Di Microteaching peserta didik berada dalam suatu lingkungan yang terbatas dan terkontrol. Guru mengajarkan hanya satu konsep dengan menggunakan satu atau dua keterampilan mengajar (Oemar Hamalik, 2009).

Pada intinya, microteaching merupakan sebuah sarana pendampingan dan latihan bagi calon guru dalam mengasah dan meningkatkan keterampilannya dalam mengajar dengan jumlah siswa lebih sedikit. 
Microteaching bertujuan untuk memberikan kesempatan bagi calon guru untuk berlatih mempraktikkan beberapa keterampilan mengajar di depan teman temannya dalam suasana yang konstruktif. Sehingga memiliki kesiapan mental, keterampilan, dan kemampuan performansi yang terintegrasi untuk bekal praktik mengajar sesungguhnya di sekolah (Jamal Ma’mur Asmani, 2010: 36).

Menurut Dwight Allen (J.J. Hasibuan, dan Moedjion, 2010: 46) tujuan microteaching adalah :

1. Bagi mahasiswa calon guru: a) Memberi pengalaman mengajar yang nyata dan latihan sejumlah keterampilan dasar mengajar secara terpisah. b) Calon guru dapat mengembangkan keterampilan mengajarnya sebelum mereka terjun ke kelas yang sebenarnya. c) Memberikan kemungkinan bagi calon guru untuk mendapatkan bermacam-macam kondisi peserta didik.

2. Bagi guru: a) Memberikan penyegaran dalam program pendidikan. b) Guru mendapatkan pengalaman mengajar yang bersifat individual demi perkembangan perofesinya. c) Mengembangkan sikap terbuka bagi guru terhadap pembaharuan yang berlangsung di pranatan pendidikan.

Dari beberapa uraian tentang tujuan pelaksanaan microteaching tersebut dapat diketahui bahwa tujuan utama pelaksanaan microteaching adalah pengembangan keterampilan mengajar melalui pengalaman mengajar yang nyata.

Adapun tujuan microteaching di FITK adalah sebagai berikut: 1) membentuk dasar-dasar pengajaran mikro. 2) melatih mahasiswa dalam menyusun perencanaan Pembelajaran termasuk di dalamnya Rencana Pelaksanaan Pembelajaran (RPP). 3) membentuk dan meningkatkan kompetensi mengajar terpadu dan utuh. 4) membentuk sikap profesional sebagai calon guru. 5) dapat menggunakan alat-alat pengajaran dengan benar dan tepat. 6) dapat mengamati keterampilan keguruan secara objektif, sistematis, kritis dan praktis. 7) dapat menerapkan teori belajar dan pembelajaran dalam suasana didaktik, pedagogok, metodik, dan andragogis secara tepat dan menarik (Panduan Microteaching, 2016).

Menurut Allen and Ryan (Imran dan Shahriar, 2013) microteaching mempunyai beberapa karakter sebagai berikut: 1) It is a real teaching situation. 2) It reduces the complexity of the real classroom teaching situation in terms of the 
number of students, the amount of time and the amount of learning contents. 3) It emphasizes training for mastery of teaching activities such as skills, techniques, methods, and curriculum selection. 4) It offers better control over practicing teaching activities because many factors easily can be manipulated to attain this greater degree of control in the training program. 5) The feedback dimension is expanded considerably because the student can receive meaningful feedback immediately after his performance, and with the help of a variety of technological teaching media as well as observation and interaction-analysis instruments can take the opportunity to improve his performance in light of the feedback provided.

Sedangkan menurut Mastromarino (2004) dikarenakan microteaching dianggap sebagai sebuah terapi untuk membantu penerapan/aplikasi dari pengetahuan calon guru maka dalam microteaching harus menggunakan lima teknik sebagai berikut: 1) role playing and video or audio recording. 2) self observational and/or supervision (monitoring). 3) reinforcement (dissonance). 4) re experimentation.5) practice of the acquired abilities. It shows people improve their performance using this method of teaching.

Sejalan dengan pendapat dari Mastromarino tersebut, Imran dan Shariar (2013) mengemukakan bahwa dalam pelaksanan microteaching sebagai sebuah terapi, mahasiswa atau calon guru berperan banyak hal.

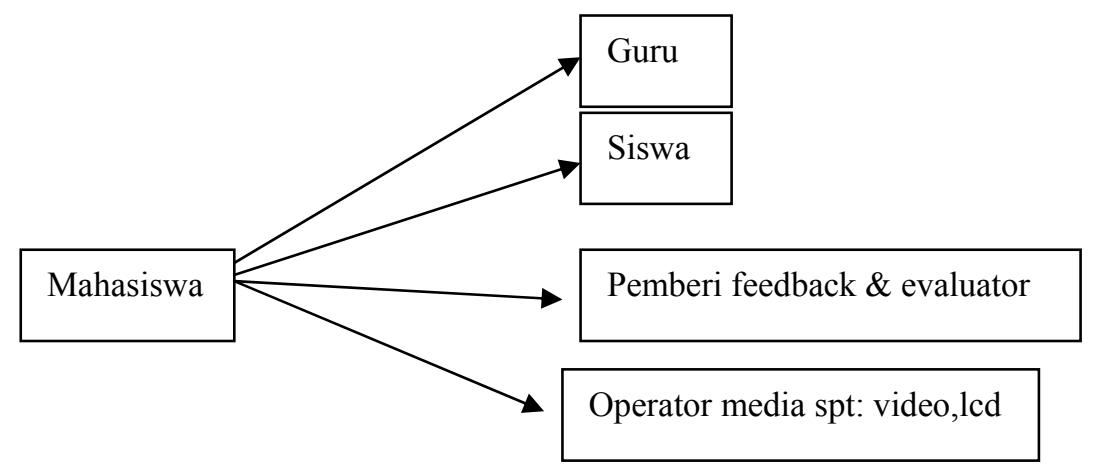

Gambar 1. Peran mahasiswa dalam microteaching

Berdasarkan ciri-ciri microteaching tersebut, dapat diuraikan secara singkat langkah-langkah dalam pelaksanaan microteaching yaitu: 


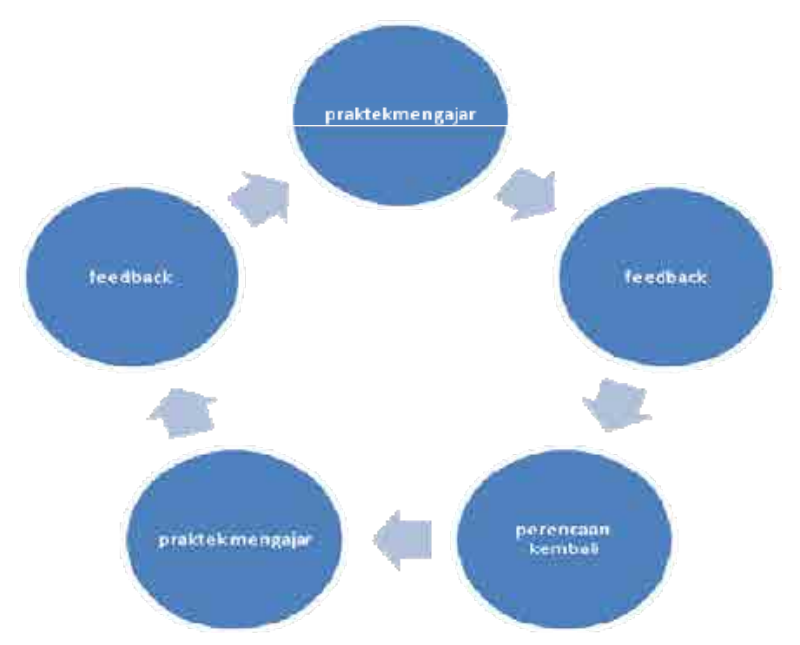

Gambar 2. Langkah-langkah microteaching

Dari gambar tersebut sangat jelas terlihat karakteristik microteaching adalah adanya pemberian feedback dan hasil dari feedback tersebut dijadikan pedoman untuk melakukan perencanaan pada praktek mengajar berikutnya. Pembelajaran microteaching di Fakultas Ilmu Tarbiyah dan Keguruan (FITK) IAIN Surakarta dilakukan dalam enam langkah sebagai berikut: 1) pengenalan microteaching, 2) penyajian model dan diskusi, 3) perencanaan/ persiapan microteaching. 4) praktek microteaching/observasi. 5) diskusi/umpan balik. 6) praktek microteaching ulang.

\section{Metode Penelitian}

Penelitian ini menggunakan jenis kuantitatif deskriptif. Penelitian dengan metode deskriptif dilakukan apabila dalam tujuannya hanya untuk mencandrakan, menggambarkan, atau mendeskripsikan hasil penelitian. Selain itu metode deskriptif ini digunakan dikarenakan dalam penelitian ini hanya mengandung satu variabel penelitian yaitu pelaksanaan microteaching.

Lokasi penelitian betempat di Fakultas Ilmu Tarbiyah dan Keguruan IAIN Surakarta dan dilakukan selama tiga bulan mulai bulan Mei-Juli 2016. Populasi dalam penelitian ini adalah mahasiswa semester 6 jurusan PAI FITK IAIN Surakarta yang berjumlah sekitar 450 orang. Berdasarkan perhitungan dari Kretjcie, jumlah 
mahasiswa yang akan dijadikan sampel sebanyak 260 orang. Teknik sampling yang digunakan adalah random sampling.

Data dikumpulkan dengan menggunakan metode dokumentasi untuk memperoleh data-data dalam bentuk catatan, antara lain: jumlah mahasiswa PAI serta data-data lain yang diperlukan dalam penelitian ini untuk mendapatkan informasi yang valid (Suharsimi Arikunto, 2006: 231). Selain itu juga menggunakan metode angket, yang berisi sejumlah pertanyaan atau pernyataan yang harus dijawab atau direspon oleh responden (Nana Syaodih, 2006: 219). Penggunaan angket ini dimaksudkan untuk memperoleh data tentang pelaksanaan microteaching pada mahasiswa jurusan PAI FITK IAIN Surakarta tahun 2016.

Pada kegiatan analisis unit data yang diperoleh dianalisis dari segi mean, median, modus, dan standar deviasi. Sementara analisis data penelitian utama menggunakan teknik persentase. Kesemuanya itu dibantu menggunakan program SPSS 17.

\section{Hasil Penelitian}

Penelitian ini menggunakan metode deskriptif sehingga dalam deskripsi berikut ini akan diuraikan secara detil hasil tiap item dari instrumen angket penelitian ini. Angket yang disebarkan merupakan perpaduan dari jenis tertutup dan terbuka. Dikatakan sebagai tertutup karena ada dua opsi jawaban yaitu "Ya" dan "Tidak", akan tetapi juga dilengkapi dengan isian yang dapat diisi secara bebas oleh responden. Parameter pengisian skor untuk angket dengan pernyataan positif adalah sebagai berikut:

1. Jika responden memilih "Ya" diberi skor 3

2. Jika responden memilih "tidak" disertai dengan penjelasan secara terbuka diberi skor 2

3. Jika responden memilih "tidak" tanpa penjelasan secara terbuka diberi skor 1

Apabila pernyataan dalam angket negatif, maka pensekorannya adalah sebagai berikut:

1. Jika responden memilih "Ya" diberi skor 1

2. Jika responden memilih "tidak" tanpa penjelasan secara terbuka diberi skor 2 
3. Jika responden memilih "tidak" disertai penjelasan secara terbuka diberi skor 3

Berikut hasil data tiap item dari instrument penelitian:

1. Item nomor 1

Isi dari item nomor 1 adalah "Dosen pembimbing menyampaikan penjelasan tentang pelaksanaan microteaching”. Berdasarkan perhitungan secara deskriptif menggunakan program SPSS 17 diperoleh hasil sebagai berikut: mean 5,9615; std 36,98960.

Tabel 1. Deskripsi item 1

\begin{tabular}{|l|c|c|c|c|c|}
\hline & & Frequency & Percent & Valid Percent & Cumulative Percent \\
\hline Valid & 3.00 & 155 & 100.0 & 100.0 & 100.0 \\
\hline
\end{tabular}

Dari data tersebut diketahui bahwa semua responden yang berjumlah 155 mahasiswa menjawab "Ya", dengan demikian semua dosen pembimbing telah menyampaikan penjelasan tentang pelaksanaan microteaching. Penjelasan tentang proses microteaching menjadi salah satu kewajiban dari pembimbing untuk menyampaikan kepada mahasiswa. Pada awal pertemuan, dijelaskan secara detil tujuan diadakannya microteaching, sistem pelaksanaan, serta tata tertib selama micro berlangsung.

\section{Item nomor 2}

Isi dari item nomor 2 adalah "Dosen menjelaskan format RPP yang digunakan dalam praktek microteaching". Berdasarkan perhitungan secara deskriptif menggunakan program SPSS 17 diperoleh hasil sebagai berikut:

Tabel 2. Deskripsi item 2

\begin{tabular}{|l|l|c|c|c|c|}
\hline & & Frequency & Percent & Valid Percent & Cumulative Percent \\
\hline \multirow{3}{*}{ Valid } & 2.00 & 10 & 6.5 & 6.5 & 6.5 \\
\cline { 2 - 6 } & 3.00 & 145 & 93.5 & 93.5 & 100.0 \\
\cline { 2 - 6 } & Total & 155 & 100.0 & 100.0 & \\
\hline
\end{tabular}

Dari data tersebut diketahui bahwa 145 responden mahasiswa menjawab "Ya", atau "Dosen menjelaskan format RPP yang digunakan dalam praktek microteaching", dan sebanyak 10 mahasiwa menjawab "tidak" atau dengan kata 
lain dosen pembimbing lapangan (DPL) mereka tidak menjelaskan format RPP yang digunakan dalam praktek microteaching. Tidak adanya penjelasan tentang format RPP disebabkan beberapa hal: 1) DPL mempersilahkan mahasiswa bebas menggunakan format RPP sesuai keinginan mahasiswa; 2) DPL hanya mengkritisi RPP yang dibuat mahasiswa jika tidak sesuai keinginan DPL.

3. Item nomor 3

Isi dari item nomor 3 adalah "Dosen menjelaskan pentingnya untuk menggunakan strategi/metode tertentu dalam praktek microteaching". Berdasarkan perhitungan secara deskriptif menggunakan program SPSS 17 diperoleh hasil sebagai berikut:

Tabel 3. Deskripsi item 3

\begin{tabular}{|l|l|c|c|c|c|}
\hline & & Frequency & Percent & Valid Percent & Cumulative Percent \\
\hline \multirow{4}{*}{ Valid } & 1.00 & 4 & 2.6 & 2.6 & 2.6 \\
\cline { 2 - 6 } & 2.00 & 9 & 5.8 & 5.8 & 8.4 \\
\cline { 2 - 6 } & 3.00 & 142 & 91.6 & 91.6 & 100.0 \\
\cline { 2 - 6 } & Total & 155 & 100.0 & 100.0 & \\
\hline
\end{tabular}

Dari data tersebut diketahui bahwa 142 responden mahasiswa menjawab "Ya", atau "Dosen menjelaskan pentingnya untuk menggunakan strategi/metode tertentu dalam praktek microteaching", dan sebanyak 9 mahasiwa menjawab "tidak" atau dengan kata lain dosen pembimbing lapangan (DPL) mereka tidak menjelaskan pentingnya untuk menggunakan strategi/metode tertentu dalam praktek microteaching. Penjelasan lebih lanjut yang diperoleh dari responden, bahwa DPL juga tidak menjelaskan prosedur penggunaan metode atau strategi dalam mengajar selama microteaching, dan tidak menjelaskan penggunaan metode tertentu dalam praktek microteaching. Sementara itu sebanyak 4 responden menjawab "tidak" tanpa disertai dengan penjelasan.

\section{Item nomor 4}

Isi dari item nomor 4 adalah "Mahasiswa diharuskan mempraktekkan strategi yang berbeda setiap praktek miroteaching". Berdasarkan perhitungan secara deskriptif menggunakan program SPSS 17 diperoleh hasil sebagai berikut: 
Tabel 4. Deskripsi item 4

\begin{tabular}{|l|l|c|c|c|c|}
\hline & & Frequency & Percent & Valid Percent & Cumulative Percent \\
\hline \multirow{4}{*}{ Valid } & 1.00 & 6 & 3.9 & 3.9 & 3.9 \\
\cline { 2 - 6 } & 2.00 & 42 & 27.1 & 27.1 & 31.0 \\
\cline { 2 - 6 } & 3.00 & 107 & 69.0 & 69.0 & 100.0 \\
\cline { 2 - 6 } & Total & 155 & 100.0 & 100.0 & \\
\hline
\end{tabular}

Dari data tersebut diketahui bahwa 107 responden mahasiswa menjawab "Ya", atau "Mahasiswa diharuskan mempraktekkan strategi yang berbeda setiap praktek miroteaching", dan sebanyak 42 mahasiwa menjawab "tidak" atau dengan kata lain dosen pembimbing lapangan (DPL) mereka tidak mengharuskan mahasiswa mempraktekkan strategi yang berbeda setiap praktek microteaching. Keterangan lebih lanjut yang diperoleh dari responden adalah: 1) DPL tidak mewajibkan mahasiswa menggunakan strategi yang berbeda dalam setiap praktek microteaching; 2) DPL membebaskan penggunaan strategi dalam mengajar selama microteaching; 3) DPL tidak terlalu memperhatikan strategi mengajar yang dilakukan oleh mahasiswa yang sedang mengajar. Adapun 6 responden menjawab "tidak" tanpa disertai dengan penjelasan.

\section{Item nomor 5}

Isi dari item nomor 5 adalah "Pelaksanaan micro dilakukan secara marathon (satu hari, semua mahasiswa dalam kelompok melakukan micro)". Berdasarkan perhitungan secara deskriptif menggunakan program SPSS 17 diperoleh hasil sebagai berikut:

Tabel 5. Deskripsi item 5

\begin{tabular}{|c|l|c|c|c|c|}
\hline \multirow{2}{*}{} & & Frequency & Percent & Valid Percent & $\begin{array}{c}\text { Cumulative } \\
\text { Percent }\end{array}$ \\
\hline \multirow{3}{*}{ Valid } & 1.00 & 46 & 29.6 & 29.6 & 29.6 \\
\cline { 2 - 6 } & 2.00 & 6 & 3.9 & 3.9 & 33.5 \\
\cline { 2 - 6 } & 3.00 & 103 & 66.5 & 66.5 & 100.0 \\
\cline { 2 - 6 } & Total & 155 & 100.0 & 100.0 & \\
\hline
\end{tabular}

Dikarenakan pernyataan pada item nomor 5 tersebut merupakan pernyataan negatif, maka pensekoran dan pemaknaan menjadi terbalik. Dari data 
tersebut diketahui bahwa 46 responden mahasiswa menjawab "Ya", atau dengan kata lain bahwa "kelompok mereka melakukan micro secara marathon (satu hari, semua mahasiswa dalam kelompok melakukan micro)", dan sebanyak 6 responden menjawab "tidak" tanpa disertai dengan penjelasan, dan sebanyak 103 mahasiwa menjawab "tidak" atau dengan kata lain kelompok mereka tidak melakukan micro secara marathon (satu hari, semua mahasiswa dalam kelompok melakukan micro). Pelaksanaan microteaching dilakukan oleh 2-6 mahasiswa setiap pertemuannya dengan metode yang berbeda-beda. Ada yang menggunakan metode penunjukan, bergilir sesuai absen, atau mempersilahkan mahasiswa yang telah siap praktek mengajar.

Kegiatan microteaching yang dilakukan secara marathon, tentunya akan berimbas pada beberapa faktor di antaranya: 1) persiapan mahasiswa; 2) perhatian mahasiswa saat microteaching; 3) kelelahan.

6. Item nomor 6

Isi dari item nomor 6 adalah "Mahasiswa membuat RPP secara langsung untuk 4x pertemuan”. Berdasarkan perhitungan secara deskriptif menggunakan program SPSS 17 diperoleh hasil sebagai berikut:

\begin{tabular}{|l|l|c|c|c|c|}
\hline \multicolumn{5}{|c|}{ Tabel 6. Deskripsi item 6 } \\
\hline \multirow{3}{*}{ Valid } & & Frequency & Percent & Valid Percent & $\begin{array}{c}\text { Cumulative } \\
\text { Percent }\end{array}$ \\
& 1.00 & 60 & 38.7 & 38.7 & 38.7 \\
& 2.00 & 8 & 5.2 & 5.2 & 43.9 \\
& 3.00 & 87 & 56.1 & 56.1 & 100.0 \\
& Total & 155 & 100.0 & 100.0 & \\
\hline
\end{tabular}

Dikarenakan pernyataan pada item nomor 6 tersebut merupakan pernyataan negatif, maka pensekoran dan pemaknaan menjadi terbalik. Dari data tersebut diketahui bahwa 60 responden mahasiswa menjawab "ya", atau dengan kata lain bahwa "Mahasiswa membuat RPP secara langsung untuk 4x pertemuan", dan sebanyak 8 mahasiwa menjawab "tidak" atau dengan kata lain "mereka tidak membuat RPP secara langsung untuk 4x pertemuan" tanpa disertai penjelasan, dan sebanyak 87 mahasiswa menjawab "tidak" atau dengan kata lain mereka tidak 
diminta untuk membuat membuat RPP secara langsung untuk 4x pertemuan". DPL hanya meminta mahasiswa membuat satu RPP untuk setiap kali praktek mengajar.

Meskipun hasil akhir microteaching adalah mahasiswa menyusun 4 jenis RPP, akan tetapi penyusunan empat buah RPP secara langsung dalam satu waktu tentunya juga berdampak bagi mahasiswa. Selain dampak persiapan, dampak lain adalah kesungguhan.

\section{Item nomor 7}

Isi dari item nomor 7 adalah "Mahasiswa melakukan praktek micro minimal 4x pertemuan”. Berdasarkan perhitungan secara deskriptif menggunakan program SPSS 17 diperoleh hasil sebagai berikut:

Tabel 7. Deskripsi item 7

\begin{tabular}{|l|l|c|c|c|c|}
\hline & & Frequency & Percent & Valid Percent & Cumulative Percent \\
\hline Valid & .00 & 1 & .6 & .6 & .6 \\
\cline { 2 - 6 } & 1.00 & 5 & 3.2 & 3.2 & 3.9 \\
\cline { 2 - 6 } & 2.00 & 8 & 5.2 & 5.2 & 9.0 \\
\cline { 2 - 6 } & 3.00 & 141 & 91 & 91 & 100.0 \\
\cline { 2 - 6 } & Total & 155 & 100.0 & 100.0 & \\
\hline
\end{tabular}

Dari data tersebut diketahui bahwa 141 responden mahasiswa menjawab "ya", atau dengan kata lain bahwa "Mahasiswa melakukan praktek micro minimal 4x pertemuan", dan sebanyak 8 mahasiwa menjawab "tidak" atau dengan kata lain "mereka tidak melakukan praktek micro minimal 4x pertemuan". Penjelasan lebih lanjut dari komentar responden adalah sebagai berikut: 1) tidak diharuskan setiap mahasiswa melakukan praktek micro minimal 4x akan tetapi apabila dua kali mengajar dirasa dosen pembimbing sudah baik dan cukup maka mahasiswa tidak melakukan micro lagi; 2) setiap mahasiswa hanya melakukan praktek micro 3x pertemuan dengan mengajar mapel yang berbeda dalam 4 rumpun PAI. Selain respon tersebut, sebanyak 5 mahasiswa menjawab "tidak" tanpa disertai dengan penjelasan, dan satu mahasiswa tidak mengisi item nomor 7 . 


\section{Item nomor 8}

Isi dari item nomor 8 adalah "Dalam prakteknya, mahasiswa dituntut untuk mampu melakukan: a) ketrampilan membuka pelajaran; b) ketrampilan verbal dan nonverbal; c) ketrampilan menggunakan media pembelajaran; d) ketrampilan memilih strategi/metode; e) ketrampilan menerangkan materi; f) ketrampilan bertanya; g) ketrampilan melakukan penilaian; h) ketrampilan mengadakan motivasi; dan g) ketrampilan menutup pelajaran.

Tabel 8. Deskripsi item 8

\begin{tabular}{|l|l|c|c|c|c|}
\hline & & Frequency & Percent & Valid Percent & Cumulative Percent \\
\hline \multirow{4}{*}{ Valid } & .00 & 2 & 1.3 & 1.3 & 1.3 \\
\cline { 2 - 6 } & 1.00 & 1 & .6 & .6 & 1.9 \\
\cline { 2 - 6 } & 3.00 & 152 & 98.1 & 98.1 & 100.0 \\
\cline { 2 - 6 } & Total & 155 & 100.0 & 100.0 & \\
\hline
\end{tabular}

Dari data tersebut diketahui bahwa 152 responden mahasiswa menjawab "ya", atau dengan kata lain bahwa "dalam prakteknya, mahasiswa dituntut untuk mampu melakukan sembilan ketrampilan sebagaimana tertulis di atas" Satu responden menjawab "tidak", tetapi tidak memberi penjelasan dari respon yang disampaikan. Sementara itu, ada dua responden yang tidak mengisi item nomor 8 .

Keterampilan mengajar yang dituntut dalam praktek microteaching terdiri dari: 1) ketrampilan membuka pelajaran; 2) ketrampilan verbal dan nonverbal; 3) ketrampilan menggunakan media pembelajaran; 4) ketrampilan memilih strategi/metode; 5) ketrampilan menerangkan materi; 6) ketrampilan bertanya; 7) ketrampilan melakukan penilaian; 8) ketrampilan mengadakan motivasi; dan 9) ketrampilan menutup pelajaran.

9. Item no. 9

Isi item nomor 9 adalah "Dosen memberikan feedback terhadap penampilan mahasiswa". Berdasarkan perhitungan secara deskriptif menggunakan program SPSS 17 diperoleh hasil sebagai berikut: 
Tabel 9. Deskripsi item 9

\begin{tabular}{|l|l|c|c|c|c|}
\hline & & Frequency & Percent & Valid Percent & Cumulative Percent \\
\hline \multirow{3}{*}{ Valid } & .00 & 1 & .6 & .6 & .6 \\
\cline { 2 - 6 } & 3.00 & 154 & 99.4 & 99.4 & 100.0 \\
\cline { 2 - 6 } & Total & 155 & 100.0 & 100.0 & \\
\hline
\end{tabular}

Dari data tersebut diketahui bahwa 154 responden mahasiswa menjawab "ya", atau dengan kata lain bahwa "Dosen memberikan feedback terhadap penampilan mahasiswa" Sementara itu, ada satu responden yang tidak mengisi item nomor 9. Pemberian feedback atas penampilan mahasiswa dalam praktik mengajar menjadi sangat penting peranannya, agar mahasiswa lebih memperhatikan performa praktik mengajar pada pertemuan berikutnya.

10. Item no. 10

Isi item nomor 10 adalah "Dosen memberikan kesempatan kepada audiens (mahasiswa lain) memberi masukan atas penampilan mahasiswa praktikan". Berdasarkan perhitungan secara deskriptif menggunakan program SPSS 17 diperoleh hasil sebagai berikut:

Tabel 10. Deskripsi item 10

\begin{tabular}{|l|l|c|c|c|c|}
\hline \multirow{4}{*}{ Valid } & & Frequency & Percent & Valid Percent & Cumulative Percent \\
\cline { 2 - 6 } & .00 & 1 & .6 & .6 & .6 \\
\cline { 2 - 6 } & 1.00 & 6 & 3.9 & 3.9 & 4.5 \\
\cline { 2 - 6 } & 2.00 & 62 & 40.0 & 40.0 & 44.5 \\
\cline { 2 - 6 } & 3.00 & 86 & 55.5 & 55.5 & 100.0 \\
\cline { 2 - 6 } & Total & 155 & 100.0 & 100.0 & \\
\hline
\end{tabular}

Dari data tersebut diketahui bahwa 86 responden mahasiswa menjawab "ya", atau dengan kata lain bahwa "Dosen memberikan kesempatan kepada audiens (mahasiswa lain) memberi masukan atas penampilan mahasiswa praktikan" Sementara itu, 62 responden menjawab "tidak" atau dengan kata lain DPL tidak memberikan kesempatan kepada mahasiswa lain untuk memberi masukan atas penampilan mahasiswa praktikan, dan hanya DPL sendiri yang 
memberi masukan. Sedangkan enam responden juga menjawab "tidak" tapi tanpa disertai alasan, dan satu responden tidak mengisi angket item nomor 10.

\section{Item no.11}

Isi item nomor 11 adalah "Dosen menilai penampilan mahasiswa secara langsung”. Berdasarkan perhitungan secara deskriptif menggunakan program SPSS 17 diperoleh hasil sebagai berikut:

Tabel 11. Deskripsi item 11

\begin{tabular}{|l|l|c|c|c|c|}
\hline & & Frequency & Percent & Valid Percent & Cumulative Percent \\
\hline Valid & .00 & 5 & 3.2 & 3.2 & 3.2 \\
\cline { 2 - 6 } & 1.00 & 1 & .6 & .6 & 3.9 \\
\cline { 2 - 6 } & 2.00 & 10 & 6.5 & 6.5 & 10.3 \\
\cline { 2 - 6 } & 3.00 & 139 & 89.7 & 89.7 & 100.0 \\
\cline { 2 - 6 } & Total & 155 & 100.0 & 100.0 & \\
\hline
\end{tabular}

Dari data tersebut diketahui bahwa 139 responden mahasiswa menjawab "ya", atau dengan kata lain bahwa "Dosen menilai penampilan mahasiswa secara langsung" Sementara itu, 10 responden menjawab "tidak" atau dengan kata lain DPL tidak menilai penampilan mahasiswa secara langsung alasan yang dikemukakan oleh responden adalah "Dosen pembimbing dikelompoknya tidak memberikan penilaian langsung setiap kali mahasiswa mengajar akan tetapi hanya mengamati penampilan mahasiswa tanpa membawa lembar penilaian".

12. Item no. 12

Isi item nomor 12 adalah "Penilaian terhadap penampilan mahasiswa diwakilkan pada teman-teman sekelas". Berdasarkan perhitungan secara deskriptif menggunakan program SPSS 17 diperoleh hasil sebagai berikut: 
Tabel 12. Deskripsi item 12

\begin{tabular}{|l|l|c|c|c|c|}
\hline & & Frequency & Percent & Valid Percent & Cumulative Percent \\
\hline \multirow{4}{*}{ Valid } & .00 & 1 & .6 & .6 & .6 \\
\cline { 2 - 6 } & 1.00 & 19 & 12.3 & 12.3 & 12.9 \\
\cline { 2 - 6 } & 2.00 & 91 & 58.7 & 58.7 & 71.6 \\
\cline { 2 - 6 } & 3.00 & 44 & 28.4 & 28.4 & 100.0 \\
\cline { 2 - 6 } & Total & 155 & 100.0 & 100.0 & \\
\hline
\end{tabular}

Ada kemungkinan ketika DPL mewakilkan penilaian mahasiswa padateman-teman sekelas bertujuan agar hasil penilaian lebih obyektif. Akan tetapi, kewajiban menilai tetap ada pada DPL maka semestinya penilaian dari mahasiswa hanya menjadi pendukung saja. Oleh karena itu, pada item nomor 6 tersebut dikategorikan sebagai pernyataan negative, maka pensekoran dan pemaknaan menjadi terbalik. Dari data tersebut diketahui bahwa 33 responden mahasiswa menjawab "ya", atau dengan kata lain bahwa "Penilaian terhadap penampilan mahasiswa diwakilkan pada teman-teman sekelas", dan sebanyak 91 mahasiwa menjawab "tidak" atau dengan kata lain "DPL tidak meminta mahasiswa lain untuk menilai penampilan mahasiswa praktikan", karena DPL itu sendiri yang menilai performance mahasiswa praktikan.

Selain angket tertutup sebagaimana telah dibahas sebelumnya, pengambilan data juga menggunakan angket terbuka untuk menanyakan beberapa hal yang berkaitan dengan urgensi Microteaching di jurusan PAI FITK IAIN Surakarta.: 1) Apakah Menurut Saudara melalui microteaching daat meningkatkan rasa percaya diri saudara dalam mengajar?; 2) Apakah menurut saudara microteaching dapat meningkatkan kemampuan mengajar anda?; 3) Pada mata kuliah strategi pembelajaran, mahasiswa sudah melakukan praktek mengajar. apakah menurut saudara, microteaching tetap perlu dilakukan?

Hasil dari tiga pertanyaan tersebut adalah sebagai berikut:

Tabel 13. Deskripsi Urgensi Microteaching

\begin{tabular}{|c|l|c|}
\hline No & \multicolumn{1}{|c|}{ Urgensi Microteaching } & Persentase (\%) \\
\hline 1 & meningkatkan percaya diri & 86 \\
\hline 2 & meningkatkan kemampuan mengajar & 92 \\
\hline 3 & microteaching tetap diberlakukan & 81 \\
\hline
\end{tabular}




\section{Kesimpulan}

Berdasarkan hasil analisis penelitian tersebut dapat disimpulkan bahwa:

1. Pelaksanaan microteaching secara keseluruhan telah memennuhi ketentuan pelaksanaan microteaching sebagaimana tercantum di buku panduan microteaching. Setiap mahasiswa melakukan praktek mengajar sebanyak 4-5 kali, sebelumnya diharuskan menyusun RPP yang selanjutnya akan dicermati dan dikoreksi oleh dosen pembimbing (DPL). Dalam melaksanakan praktek mengajar, mahasiswa dituntut mempraktekkan salah satu strategi mengajar yang sesuai dengan materi yang akan disampaikan. Setelah selesai praktek mengajar, DPL akan memberikan masukan terkait penampilan mahasiswa tersebut.

2. Meskipun mahasiswa telah memperoleh beberapa mata kuliah strategi pembelajaran yang notabene lebih banyak berisi praktek mengajar baik secara kelompok maupun individu, namun $81 \%$ mahasiswa menyatakan bahwa microteaching masih sangat diperlukan. Menurut mereka, dikarenakan microteaching dapat meningkatkan kemampuan mengajar dan kepercayaan diri mahasiswa.

\section{Daftar Pustaka}

Ajileye, Mosunmola Ajibola. 2013. Effects of microteaching skills on studentteachers' performance on teaching practicein colleges of education, north-central, Nigeria. Department of Educational Technology, University of Ilorin, Ilorin, Nigeria.

Asmani, Jamal Ma'mur. 2010. Pengenalan dan Pelaksanaan Lengkap Microteaching danTeam Teaching. Yogyakarta: Diva Press

Asril, Zaenal. 2011. Micro Teaching. Jakarta: Radja Grafindo Persada

B C. Ijioma, Dr. M. N. Obasi \& Dr. P.C Ifegbo. 2014. Integrating Microteachin g Theory + Practice in Concurrent and Consecutive Teacher Education Programmes: Benefits and Challenges.. Report and Opinion 2014; 6(9) http://www.sciencepub.net/report

B. Veena Kumari and Digumarti Bhaskara Rao. (2004) Methods of Theaching Social Studies. New Delhi : Dynamic Printers Delhi 
Imran Mahmud, Shahriar Rawshon. 2013. Micro Teaching to Improve Teaching Method: An Analysis onStudents' Perspectives. IOSR Journal of Research \& Method in Education (IOSR-JRME)e-ISSN: 2320-7388,p-ISSN: 2320-737X Volume 1, Issue 4 (May. -Jun. 2013), PP 69-76www.iosrjournals.org

J.J. Hasibuan, dan Moedjiono. 2010. Proses Belajar Mengajar. Bandung: Remaja Rosdakarya

Mastromarino, R. 2004. The use of microteaching in learning the redecision model: A proposal for an observation grid. Transactional Analysis Journal, 34, 1, 3747

Nana Syaodih Sukmadinata. 2011. Metode Penelitian Pendidikan. Bandung: Remaja Rosdakarya

Oemar Hamalik. 2009. Pendidikan Guru Berdasarkan Pendekatan Kompetensi. Jakarta: Bumi Aksara

Sri Slamet. 2014. Evaluasi Pengajaran Micro Teaching Berbahasa Inggris Pada Jurusan Non Bahasa Inggris https://publikasiilmiah.ums.ac.id/ bitstream/handle/11617/5641/Evaluasi\%20Pengajaan\%20Micro\%20Teaching $\% 20$ Berbahasa $\% 20$ Inggris.pdf?sequence $=1$

Team Microteaching FITK. 2016. Buku Panduan Micro Teaching. Surakarta: FATABA Press. 
194 Khuriyah

Analisis Pelaksanaan Microteaching Mahasiswa Program Studi Pendidikan Agama Islam

at.tontaws | Volume. 2, No. 2, Juli-Desember 2017 